\title{
NOTES ON THE GEOLOGY OF THE ENGLISH LAKE DISTRICT.
}

BY J. E. MARR, M.A., F.R.S.

(Read July 6th, rgo.)

A.-INTRODUCTION.

THE Council of your Association has done me the honour of 1 inviting me to act as Director of an excursion to Lakeland in the course of the summer. In these circumstances, as I have been engaged in studying the geology of the district for many years, and have arrived at certain conclusions which have not hitherto been published, I may be pardoned if I incorporate among notes which may serve to give some idea of the general structure of the district, a summary of such conclusions; especially as, in my opinion, a knowledge of them is requisite to a right understanding of the actual structure.

For several seasons I have had the pleasure of working in Cumbria with my colleague, Mr. Alfred Harker. Many of the facts and conclusions recorded in this paper are the result of this joint work, and my colleague shares with me the credit for any records which may be of value. I shall endeavour in the paper to point out clearly such portions as must be regarded as the joint work of Mr. Harker and myself. I have obtained his permission to give this brief preliminary outline of the results of our work, and should any errors be found therein I ask that I alone may be considered responsible for them.

It is well-known that the heart of Lakeland is composed of Lower Palæozoic rocks, and that around these is a girdle of later deposits of Carboniferous, Permian, and Triassic ages.

The sub-division of the Lower Palroozoic rocks into three great natural lithological groups was first made by Jonathan Otley, in a paper in the Lonsdale Magasine (vol. i, r820, p. 433), and this tripartite grouping has been always recognised by subsequent writers, though the names applied to the groups vary in different memoirs. The following table will show the nature of the rocks:

Upper Slates (with Coniston Limestone at base), flags, grits, and slates.

Middle Slates ("Green Slates and Porphyries," "Borrodale Series"), volcanic rocks.

Lower Slates (Skiddaw Slates), dark argillaceous rocks with interbedded grits.

As regards the geographical distribution of these divisions, (leaving minor complications out of account for the moment), it may be stated that the axis of uplift of the main anticline Proc. Geol. Assoc., Vol. XVI, Part 9, Auguist, 1900.] 
into which the slates are folded runs through Skiddaw in an E.N.E.-W.S.W. direction, and that the Lower Slates or Skiddaw Slates are developed to the north and south of this axis. On the north side they are succeeded by a narrow and somewhat remarkable band of the "Middle Slates" (here only styled slates for convenience) which runs from near Greystoke Park, a few miles west of Penrith, to Cockermouth. The southern boundary of the Skiddaw Slates, where they are again succeeded by the Middle Slates (or Green Slates and Porphyries), commences on the east at the north-east or lower end of Ullswater, is traceable thence to the south end of Derwentwater, thence past Buttermere and Ennerdale Lakes, and on to the neighbourhood of Egremont, on the west of the district. The junction between Middle and Upper Slates is well defined by the Coniston Limestone, which, starting near Shap, strikes across the heads of Windermere and Coniston Lakes, and then past Broughton Mills, to the south-west of Cumberland at Millom.

The actual age of most of the deposits, owing to comparative rarity of fossils, was for a long time a matter of dispute, and even at the present day the geological horizon of some of the groups of rocks can scarcely be regarded as settled.

For many years there was a general consensus of opinion as regards the general age of the three main groups above noticed. The Skiddaw Slates, on account of the nature of their included organisms, were referred to the Arenig epoch; the middle division was considered to be of the Llandeilo cpoch; while the upper division was believed to have representatives of strata from Caradoc to Ludlow, both inclusive. As the result of detailed study of the fossils the correctness of the last correlation has been firmly established, but doubt has been thrown on the other two, and especially upon the second. I shall attempt to show, however, that in each case the reference is mainly correct.

The attention of the visitors to Lakeland in August next will be chiefly called to the Lower and Middle series of slates, which are well developed in the neighbourhood of Keswick, the headquarters of the party; and it will be necessary to pay special regard to the character of these two groups. In so doing I shall assume that the reader will peruse these notes with the aid of the published maps of H.M. Geological Survey.

Keswick is situated some way north of the centre of Quartersheet Ior S.E. (Sheet 29, New Series), and it is over the ground represented in this quarter-sheet that most of the excursions will be conducted, though one will be largely on ground represented on the Quarter-sheet lying immediately to the east (IO2 S.IV., Sheet 30, New Series).

N.B.--Members will find a geological map of the district facing p. $5^{28}$ of the "Record of Excursions." 


\section{B.-IDESCRIPTION OF LOIVER PALAOZOIC ROCKS.}

\section{I.-The Skiddaw Slates.}

Distribution.- The extent of the main mass of Skiddaw Slates has already been noticed. It is important for our purpose to note, in addition, the occurrence of other oulcrops. In the neighbourhood of Ullswater an isolated patch is separated from the main mass by the conglomerate of Mell Fell, to be referred to subsequently; beneath this it probably continues to join the main mass. South of the Ullswater patch is an extensive patch stretching from the hamlet of Butterwick to the vicinity of Shap.

In the Lower Palrozoic inlier of the Cross Fell range, east of Eden, is a continuous patch of these slates, stretching nearly the entire distance of that outlier. In the extreme southern extremity of Cumberland an isolated outcrop of Skiddaw Slate forms the hill known as Black Combe, and a smaller patch occurs on the opposite side of the Duddon estuary, to the north of Dalton-inFurness. 'The significance of these outcrops to the south of the main mass will be eventually considered.

Lithologrical Characters. - There is a general sameness in the characters of the whole group, though the rocks often differ considerably in detail. Shales, slates, and grits are the dominant rocks, and detrital mica is usually abundant. Carbonate of lime is practically absent, except in mineral veins traversing the rocks. The shales vary in culour from bluish-grey, or sometimes greenishgrey, to black. In texture they may be hard and splintery, or soft and earthy. Many of them are cleaved, though they never give rise to roofing slates of such utility as those of the Middie Slates; in other places cleavage is absent, and this is especially marked in the more northerly part of the main expanse.

The grits are very variable. Some, like the "Skiddaw Grit," are coarse quartzose rocks, sometimes becoming conglomeratic; others are much finer and are often laminated. These contain varying proportions of muddy matter, and so pass gradually into the shales and slates. Many of the arenaceous beds seem to be affected by true ripple-marks, and were probably deposited in shallow water, though in other cases structures simulating ripplemarks seem to have been caused by subsequent movements.

The presence of volcanic rocks in the upper part of the Skiddaw Slates is a fact of considerable interest. Mr. Clifton Ward inserts intercalated volcanic rocks in the beds near the contact with the Middle Slates, at the Hollows Farm, near Grange, in Borrodale, and at the south-west end of Crummock Lake. Other volcanic rocks are intercalated with the higher Skiddaw Slates of the neighbourhood of Shap, and also in those of the Cross Fell inlier. 
With our present knowledge, any attempt to subdivide and classify the Skiddaw Slates by reference to their lithological characters only, would be premature.

The thickness of the group was estimated by Mr. Clifton Ward as at least 10,000 or 12,000 feet. As will be seen presently, however, it is very difficult to judge of the amount of repetition which may have occurred owing to subsequent folding and faulting.

Age of the Slates: the Fossil Evidence.-The occurrence of fossils in these slates has long been known; of recent years the number of recorded species has been largely increased, owing mainly to the work of assiduous local observers, of whom special mention may be made of the late Mr. Kinsey Dover and Mr. J. Postlethwaite. To the labours of the latter gentleman we may look forward in expectation of a still further increase in the number of forms discovered. The latest discoveries confirm the eariier, and indicate that the main mass of the fossiliferous Skiddaw Slates is of Arenig age, though some Tremadoc forms probably occur, and possibly also some Llandeilo species. This conclusion is reached by Miss Elles, the latest student of the Skiddaw Slate fauna. The fossils, however, are by no means uniformly distributed through the slates. They are commonest in, though by no means confined to, the black slates, especially those of an earthy texture. More important is the fact that the fossiliferous bands often run in linear belts. The most marked commences in the upper part of the Glenderamakin Valley, is traceable along the ridge of Saddleback, and is possibly continued on the west side of the Derwent Valley, crossing the lower part of the Whinlatter Pass, forming the top of Grizedale Pike, and reaching Whiteside, near the foot of Crummock. On either side of these belts of fossiliferous rock lie the great grit bands, and at present there is no evidence as to the age of the latter, except that, for reasons to be given later, they can hardly be newer than the fossiliferous Skiddaw Slates, and as the latter are not likely to alter their characters so rapidly when traced across the strike, they are probably not contemporaneous with them. The probability, therefore, is that they are older, though how much older one cannot say. It is to be hoped that local observers will examine these rocks very carefully, and endeavour to find fossils in some of them.

Next to the Graptolites the Trilobites are the most abundant fossils hitherto discovered. Most of these appear to belong to the higher beds of the Skiddaw Slates, and the assemblage is essentially one which recalls that characteristic of the fauna of Dr. Hicks' Llanvirn group. In this connection it is interesting to recall the record by Mr. Kynaston of Placoparia, a form more frequently discovered in Central European rocks of this age, though also found at St. David's. 


\section{II.-The Green Slates and Porphyies or Volcanic ROCKS OF BORRODALE.*}

I specially wish to retain the title "Green Slates and Porphyries" for these beds, not only as really very descriptive, but because the alternative title introduces the name of a locality where the series is by no means typically developed. Mr. Harker and I recognise the following divisions among the volcanic rocks of this series, which are given in descending order :

Shap Rhyolites.

Shap Andesites. Band.

Scawfell banded ashes and breccias $==$ Kentmere-Coniston Slate

Uliswater basic lava group $=$ Eycott group.

Falcon Crag and Bleaberry Fell Andesites.

This division does not differ very notably except in detail from that given hy Mr. Clifton Ward in his Horizontal Section, No 3, illustrating his paper "On the Physical History of the English Lake I)istrict" (Geol. Mag., Dec. II, vol. vi, p. 54).

We have reasons for believing that the Yewdale breccia belongs to the series of Shap rnyolites, and is separated from the rocks on the summit of High White Stones by the Shap andesites. The divisions $\mathrm{A}, \mathrm{B}$, and $\mathrm{C}$ of $\mathrm{Mr}$. Ward's section just mentioned, on High White Stones, we refer to the Scawfell ashes and breccias. D, E. F, and $G$ partly correspond with the Ullswater lavas, but the main mass along the line of section consists of flinty, often streaky rocks, frequently containing felspar crystals of considerable size, and also furnishing, in many places, abundance of garnets. Of these rocks more will be said anon. Lastly group $\mathrm{H}$ contains the Falcon $\mathrm{Crag}$ and Bleaberry Fell andesites, though the lower part of the basic group may be included in it, along the line of section; the section, however, is on too small a scale to enable us to judge of this with certainty.

The following section from I)erwentwater to Coniston (Fig. r) shows the relationship of the different divisions:

\section{DESCRIPTION OF THF MAIN CHARACTERS OF THE DIFFERENT (;ROUPS, AND OF THEIR GENERAL DISTRIBUTION.}

(i.) Falcon Crag and Bleatierry Fiell Andesites.-These rocks were selected by Mr. Ward as typical of the lavas and ashes, and were very fully described by him in the memoir of "The Geology of the Northern Part of the English Lake District," pp. I 3-ig. They form a syncline between the Valley of St. John and that in which Derwentwater is situated, and extend from the junction with

- This description of the voltanic rocks (II.) nust be regaried as the joint work of $\mathbf{M r}$. Harker and myself, though I alcne am responsible for the manner in which it is given. 


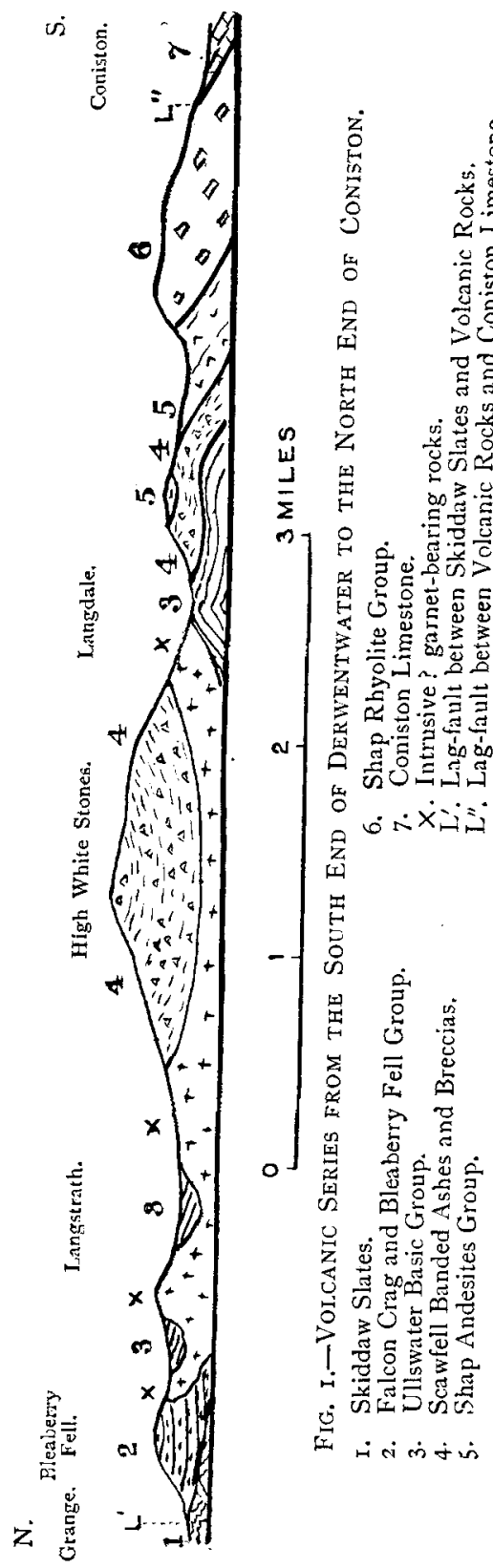

the Skiddaw Slates on the north to the neighbourhood of Watendlath Tarn on the south. It is doubtful whether they are represented in any other part of the district, though some of the lower rocks just above the junction with the Skiddaw Slates between Shap and Ullswater may appertain to them, for lavas from Pooley Bridge, and Crag's Mill, Shap, tive silica percentages of $5^{8.65}$ and 61.95 respectively. A condensed description of the rocks may also be found in a paper "On the Geology of the Neighbourhood of Keswick," written with reference to the last excursion of the Association to the district by your then President, Mr. W. H. Hudleston."

The individual lavas, on the whole, are rather thin, and accordingly vesicular structure is particularly frequent. They are associated with ashes and breccias. (The nature of the basal purple breccia will be discussed later.) The lavas are usualiy of intermediate composition, with a silica percentage of 59 to $6 \mathrm{I}$, and a specific gravity 2.65 to $2 * 7$, but it could hardly be expected that all the lavas should have a percentage within these limits, and as a matter of fact we find that one of the lavas in Ward's typical "Falcon Crag Section" (probably the base of his No. 5 lava), has a

\footnotetext{
* Prot, Geol. Assoc., vol. vii, p. 213.
} 
silica percentage of 54.35 , thus closely approaching the normal basic lavas of the district. It is expected that further examination will furnish us with other basic rocks appertaining to the Falcon Crag division.

As regards the general characters of these intermediate lavas "they are pyroxene-andesites, the pyroxene being sometimes a rhombic one (hypersthene), sometimes a monoclinic (augite), or the two often occurring together. These minerals are not in crystals large enough to be easily detected by the eye, though the dark patches due to their decomposition-products may often be observed. Porphyritic felspars are usually present, sometimes rather crowded and up to a quarter of an inch long, but more usually scattered, and often minute. The ground mass has a very compact look, with usually either a pale greenish or dark grey tint. Many of the flows are vesicular, and the vesicles may reach considerable dimensions, as, for instance, on some parts of Grange Fells. They are commonly filled with chalcedony, agate, calcite, chloritoid substances, etc., in concentric layers.

"Some of the andesites have a special character in the occurrence of little red garnets."*

The lavas and ashes of this group are of interest on account of the slight changes which they have undergone as the result of subsequent earth movements, except towards their southern extremity. The ordinary features of volcanic rocks may accordingly be readily studied in them. Many of the lavas show marked tabular jointing, as, for instance, Ward's No. 4 on Falcon Crag, and a lava which is seen on the roadside between Lowdore and Grange. Ward records garnets in the ash intervening between his lavas $\mathrm{I}$ and 2 on Falcon Crag. They are viry minute.

(ii.) Ullswater Basic Group=Eycott Group.-We have adopted the name Ullswater Group for this series of volcanic rocks, as they are extremely well developed among the hills around the upper part of Ullswater. They appear, however, to be the most widely distributed of all the divisions marked by presence of abundant lava flows, though the area covered by them may perhaps be exceeded by that occupied by the Scawfell ashes and their equivalent slate band to the south. The detection of this Ullswater group is a matter of considerable importance as throwing light upon a matter which has puzzled previous writers, namely, the whereabouts in the main development of the Green Slates and Porphyries of the equivalents of the well-known Eycott Hill volcanic rocks which occur on the northern side of the great Skiddaw anticline.

These Eycott rocks, which sweep round from Eycott Hill,

\footnotetext{
* Harker, A.- "The Ancient Lavas of the English Lake District," The Naturalist, May, 1891 . See also papers by the same author, "Chemical Notes on Lake District Rocks," Ibid., February and May, I899.
} 
near Greystoke, on the north side of Carrock to the neighbourhood of Cockermouth, form the subject of a special memoir by Mr. Clifton Ward.* "They contain $5 \mathrm{I}$ to 53 per cent. of silica, and have a specific gravity of about $2.75 . "$ "Unlike most lavas of similar chemical composition they contain no olivine, but instead we find other basic minerals abundant, and particularly hypersthene; so that the rocks may be termed hypersthenebasalts." + The very striking lava occurring near the base of the group at Eycott $\mathrm{Hill}$ is well known. It contains large crystals of bytownite felspar, an inch or even two inches across.

We first detected the basic series of lavas and their associated fragmental rocks in the area of main development of the Green Slates and Porphyries while studying the phenomena connected with the metamorphism produced by the Shap Granite, but further study soon showed us the wide extent over which these rocks occurred. They are abundantly seen around Haweswater, where they present striking similarities to the typical lavas of Eycott Hill, and anyone studying the lavas of the Haweswater region would be at once convinced of the general identity of these with those of Eycott, even apart from chemical and microscopic study. One of these lavas of the Eycott type, with large felspar phenocrysts, from Randal Beck, Mardale, has a silica percentage of $53^{*} 45$, with specific gravity $2 \cdot 73^{6}$. As already remarked, they are extremely well developed around Ullswater, and may be traced over Helvellyn to the Vale of St. John. In Borrodale they do not appear in great force on the east side, though the members of the Association wiil probably have an opportunity of seeing them at Galleny Force, at the foot of Greenup Gill (a specimen from this locality has a silica percentage 52.6 , and sp. gr. $2 \cdot 757$ ). On the west side of Borrodale they appear to be developed in force, and may be traced hence over Honister Pass (where the workable slates are associated with them), and thence by the head of Ennerdale to Wastwater, where they are again developed in considerable force. On the south side of the great mass of Scawfell ashes, which occupies the central part of the district, they are developed in the narrow band of country between these ashes and the equivalent slate band which runs from near Shap to Coniston, as seen in the Section (Fig. I).

There is considerable variation among the lavas of the group. The large porphyritic felspars, which are so prominent in some of the Eycott Hill rocks are fairly frequent, but in the greater number of lavas which contain phenocrysts, these are of a ferromagnesian mineral and not felspar. Many of the features which are observable in the andesitic group are also noticeable here; in fact the similarity is usually so great that it would be difficult to

\footnotetext{
* "On the Lower Silurian Lavas of Eycott Hill, Cumberland," by J. Clifton Ward. Monthly Microscopical Journal, 1877 .

+ Harker, Alfred, The Naturaiist, May, 1892.
} 
separate the two groups from one another without having recourse to chemical analyses. A considerable number of these have been made (or, at any rate, silica percentages determined), and are recorded in the paper in The Naturalist to which reference has already been given.

(iii.) Scawfell Banded Ashes and Breccias, and KentmereConiston Slate Band.-The presence of very fine and well bedded ashes is by no means characteristic of this division; indeed, we are accustomed to meet with them in every division of the Green Slates and Porphyries, and their presence in the Honister rocks has just been alluded to. The reason for separating the present division from others is the great development and preponderance of ashes therein, lavas being few in number and only locally developed. The Scawfell ashes are typically developed in the Scawfell group, and it is there that the members of the Association will have an opportunity of studying them. They practically form the watershed between the rivers flowing north and those flowing south in the heart of the district. In the east, they are first found on the spur of the High Street range which scparates Haweswater from Ullswater. From High Street a tongue is sent off past Mardale to the east side of Haweswater. The main mass continues westward, forming the great mass of Fairfieid, Red Screes, and the upper part of Helvellyn, whence a tongue runs to the head of Ullswater. It is cut through by the Dunmail Raise Pass, but the ashes set in on the west side of that pass, and are continued by High White Stones to the Scawfell group. Here they trend southward to the Coniston chain, being again cut through by Wrynose Pass. They form the summits of the Coniston Fells, and here send off a third tongue into the Duddon Valley.

Returning to the neighbourhood of Shap, we meet with a workable slate band in the valley of Mosedale, west of Shap Wells. This is reacily traceable in a series of quarries, and runs by I.ong Sleddale, Kentmere, and Troutbeck, and along the fells at the heads of Windermere and Coniston Lakes to a point near the village of Torver, where it suddenly abuts against the Coniston Limestone. 'The ashes of this slate band appear at first sight very different from those of the Scawfell group, but we were soon convinced of their general identity, and afterwards obtained conclusive evidence on this point. The two seem to run together on Red Screes; but the most striking evidence is seen at Walney Scar, west of Coniston I ake, where the slate band and Scawfell ash group come together, and can be actually traced into one another, though a remarkably sudden change in the lithological characters of the rocks is noticeable at this place.

I shall here notice only those characters of the group which appear to be original, leaving the study of the features produced by subsequent changes for consideration in another section of the paper. 
The most striking feature is the banding of the rocks, which may be studied on various scales; the marked bedded structure is often seen at a distance, as in the Scawfell group viewed from near the head of Eskdale, or in the great precipice of Helvellyn, as seen from Red Tarn. A nearer approach shows well-marked escarpments and dip-slopes on a smaller scale, due to minor divisional planes of bedding. These may be studied between Sty Head and Sprinkling Tarns. On still closer inspection, finer lines of lamination may often be observed in the ashes, which are even of microscopic minuteness in the very finest ashes. There is no doubt that extensive movement has occurred along many of these planes, but they were obviously bedding planes as originally developed.

Associated with the finer ashes (the finest of which must have been showered out as volcanic dust) are breccias of every degree of coarseness. Many of these are obviously true breccias of explosion, others as obviously are not, while in many cases it is impossible to state to what cause a breccia is due. This point will be considered later.

The composition of the ashes is variable, as might be expected from the fact that they occur above a basic group of lavas and below an intermediate group. In the Scawfell area an ash from the upper part of Eskdale has a silica percentage $63^{\circ} \mathrm{I}$ and $\mathrm{sp}$. gr. $2 \cdot 755$, while another from Hanging Knotts gave silica per cent. 56.60 , sp. gr. $2 \cdot 667$. Of two rocks from the slate band, one from a quarry at Grasmere has a silica percentage of $6 \mathbf{r}^{\cdot} 75$, and another from Tilberthwaite $6 \mathrm{r}^{\cdot 25}$.

The slates of Troutbeck are associated with thin vesicular lavas, and lavas are probably intercalated with the ashes in other localities.

(iv.) Shap Andesites.-A description of these rocks is given in our paper on the Shap Granite. At Shap they occur in contact with the Ullswater group, as the ashes of the slate band are here faulted out, but farther west, as already stated, the ashes of this slate band come in at Mosedale. The Shap andesites are traceable as a continuous band from Shap to the neighbourhood of Torver, where they, like the beds of the slate band, abut against the Coniston Limestone, but reappear again near Broughton-inFurness.

Outliers of this group appear on several hill-tops above the Scawfell banded ashes. They are found on the summits of Red Screes, Helvellyn, and the hills on the east and west side of Langdale.

The lavas are usually thin, and consequently vesicular. A specimen from between Wasdale Pike and Great Yarlside, west of Shap Wells, has a silica-percentage $59^{\circ} 95$ and sp. gr. $2 \cdot 73^{6}$.

(v.) Shap Rhyolites. - These rocks are also described in our paper on the Shap Granite. They extend from Shap to near 
Torver, and reappear in considerable force in the neighbourhood of Millom. No definite passage can be traced from the rhyolites which succeed the andesites and those which are associated with the Coniston Limestone and with fossiliferous ashes; but from their general resemblance, there is little doubt that there was originally a passage. Many of the rhyolites show remarkable nodular structures, which are specially well seen on Great Yarlside.

\section{III.-ThE UPPER SLATES.}

A very short account of these rocks will suffice. They are subdivided into the following groups in descending order:

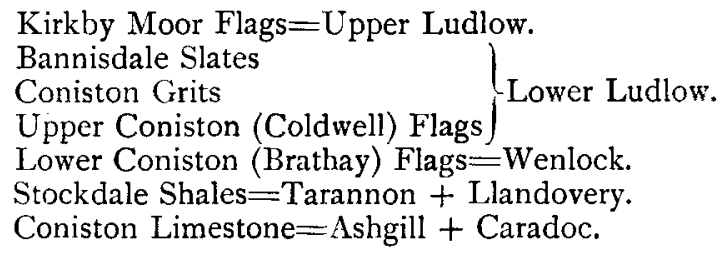

The Coniston Limestone outcrop, as before stated, runs from Shap Wells to Millom. The group also appears on the east side of the Duddon Valley, in the neighbourhood of Dalton-in-Furness. The representatives of the Coniston Limestone are further found in the Cross Fell inlier. Of particular import is the occurrence of deposits of this age towards the extreme north of the district, at Dry Gill, in the Caldbeck Fells. A local unconformity occurs in the centre of the Coniston Limestone group. Evidences for this are seen in Stockdale and at High Pike Haw near Torver.

The Stockdale shales are of interest to us in this place, on account of their lithological characters. They consist of a thin deposit of soft black shales, succeeded by a thicker mass of harder beds containing massive grits.

The Brathay flags are fine-grained, as are the Coldwell beds to a great extent, while the Coniston grits are massive grits with few argillaceous seams.

The Bannisdale slates consist of finely laminated gritty shales interstratified with frequent thin grits, and the Kirkby Moor Flags are gritty flags and grits.

The Upper Slates are developed in the Lake District proper in the comparatively low ground south of the junction with the Green Slates and Porphyries. They form also the Howgill Fells on the east side of the Lune Valley, and travellers to Keswick by the London and North Western Railway will be able to judge of their general characters, as they are developed in force between the stations of Oxenholme and Tebay. 


\section{C.-CHANGES AT THE ClOSE OF LOWER PALAOZOIC TIMES.*}

(i.) Previous Viecus on the Structure.

It has long been known that the movements which gave the prevalent E.N.E.-W.S.W. strike to the Lower Palæozoic rocks of Lakeland occurred before the deposition of the Carboniferous rocks, which are unaffected by these movements, and it has long been recognised that the apparent structure of the axis of the district is that of a great anticline, of which the Skiddaw Slates occupy the centre, while the Green Slates and Porphyries rest upon them on the north and south, and the Upper Slates rest upon the Green Slates and Porphyries on the south.

It has also been long recognised that this main anticlinal fold is complicated by many minor folds and faults ; for many years, however, these were not considered of sufficient importance to cause any great difference between the original succession and that which at present exists.

As the result of the detailed mapping of the members of H.M. Geological Survey, and especially of the late Mr. Clifton Ward, it became apparent that the junction between the Skiddaw Slates and the Green Slates and Porphyries was not a normal one, and three explanations have been hitherto suggested to account for the appearances presented at this junction.

I. Mr. Dakyns, in a short paper in the Geological Magazine (Decade I, vol. vi, r 869 , p. 56), gives reasons for supposing that the junction is an uncomformable one.

2. Mr. Ward represents the junction as a faulted one. The faults are represented in his sections with fissures approaching the vertical, and over a considerable distance along the line of junction, that junction is represented as one consisting of two sets of faults, one of which is nearly at right angles to the other. As Mr. Ward remarks in the memoir on the Keswick Quartersheet (p. 48), "The boundary, in fact, appears to be formed by the constant meeting of faults having a more or less north and south direction with others having a more or less east and west course, the two frequently meeting at right angles with each other, and letting down the rocks between them."

3. Some years since, the junction was freely spoken of among geologists more or less acquainted with the district, as being probably of the nature of an overthrust-plane. I believe this opinion has received its expression in print, but am unable, at the moment, to find the reference. As no evidence was adduced in support of it, the matter is unimportant.

At the time when the first two views were put forward, the study of the effects of earth-movement was by no means in so

* Section $\mathrm{C}$ is a record of work carried out by Mr. Harker and myself. As before, I am responsible for the mode of expression. 
advanced a state as at present, and in particular, the existence of reversed faults was supposed to be extremely rare, while faults with a fissure approaching the horizontal were practically ignored. In these circumstances the nature of the junction between the Skiddaw Slates and the Green Slates and Porphyries was of necessity a puzzle, and it is not surprising that Messrs. Dakyns and Ward should have offered these explanations. It gives me much pleasure to bear testimony to the accuracy with which the main facts were noted by these writers. Both evidently saw difficulties in explaining the actual facts, as they observed them, in accordance with opinions which were then current, but they nevertheless did faithfully record these facts, and accordingly gave most important help to subsequent workers. While on this subject I would also bear witness to the extreme accuracy of Mr. W. T. Aveline's maps of the southern part of the district. The views which we put forward would not have been arrived at so soon, if at all, had it not been for our study of the published maps of the Geological Survey, and we feel it only rigbt to express an acknowledgment of the assistance which we ha: $e$ received from these maps, and their accompanying sections and memoirs.

(ii.) General Statement of our Vicaes.

(a) It is our opinion that the present succession of the rocks in the district is, on the whole, the original one; that the Skiddaw Slates are succeeded in order by the Green Slates and Porphyries, and these by the Upper Slates. We find no evidence that the Green Slates and Porphyries are older that the Skiddaw Slates, and have been thrust over them along a thrust-plane.

(b) We consider that the folding and faulting which have affected the Lower Palæozoic rocks of the district are primarily due to the pushing forward of the rocks in a general northerly direction by a force acting from the south.

(c) Further, that the rocks moved forward at unequal rates, and that, so far as the main mass of rocks now exposed is concerned, the Skiddaw Slates moved farthest forward, causing the Green Slates and Porphyries to lag behind, and the Upper Slates in turn to lag behind the Green Slates and Porphyries.

(d) As the result of the lagging, we believe that a fault, whose fissure approaches the horizontal, was formed between the Skiddaw Slates and the Green Slates and Porphyries, and a similar fissure between these volcanic rocks and the Lpper Slates. These fissures, it will be noticed, would have an outcrop similar to those of thrust-planes or over-faults which approached the horizontal ; but they would differ from these, inasmuch as no inversion on a large scale would accompany them. We shall speak of them here as "lag" faults.

(e) The slices of rock defined by these great strike-faults would be affected by minor folds and faults, which would often abut against the great strike-faults. 
(f) We consider that the evidence further shows that each of these great slices moved forward with different velocity in different parts. Thus, if the right hand portion of a rock-slice moved forward more rapidly than the left hand portion, and the rock would not stretch, it would be fractured, and the right hand portion would be pushed nearly horizontally past the left hand portion along a vertical or nearly vertical line of fracture. These faults would be dip-faults, but the displacement would be backward and forward, and not an upward and downward one. We have been accustomed to speak of these faults as "tears," and for convenience may use the term here, for the rocks are torn from one another. These "tears" correspond in some respects with the minor thrusts occurring between the main thrust-planes in a district which has been affected by overthrusting.

$(g)$ Owing to these movements the rocks of the district would be broken up into rectangular or rhomboidal blocks, in each of which two sides would be defined by strike-faults and the other two by dip-faults.

(h) If this general thrusting in a northerly direction took place, we should find signs of overthrusting somewhere to the north, for the rocks travelling onward must have travelled over some other rocks. 'There seems no evidence of the extensive outcrop of the overthrust in the I ake District proper, but evidence points to the possibility of the Irygill Shales being beneath the great overthrust, and to the same thrust being the plane of separation between the Skiddaw Slates and the Upper Slates of the Cross Fell inlier.

(i) Such movement should be marked by many minor mechanical changes, and possibly also by chemical changes in the rocks of the district. We propose to offer evidence of the occurrence of these changes in a very considerable degree.

(iii) General Ezidence for the Faults.

(a) The Overthrust.-Owing to the paucity of sections, little evidence can be brought forward in favour of the actual existence of the overthrust (which must occur somewhere, assuming that our views are correct) in the present district. The position of the 1)rygill Shales is so extraordinary that the late Professor Nicholson and I were reluctant to place the beds in the position to which they seemed to belong after study of their fossils, but further study convinced me that these beds were really of the age of the Coniston Iimestone, and Miss Wood and Miss Elles eventually proved beyond doubt that this was the case. These shales occur on the north side of the Carrock Fell igneous rocks, and to the north of them are rocks of the Eycott group. Their existence in this position is best explained, on the supposition that they occur beneath an overthrust, and in confirmation of this, I may point out that they approach rather to the Scotch type of deposit than to that which characterises the main line of outcrop of the Coniston 
Limestone group. The beds have undoubtedly br: $n$ affected by other changes, including intrusion of igneous rock, which may have carried them to their present elevation.

In the Cross Fell inlier, the junction between the Skiddaw Slates on the east and the Upper Slates on the west is mapped as a faulted one. Here again, subsequent changes have occurred as the result of post-Carboniferous movements, but several facts point to the existence of the Skiddaws above the Upper Slates. The Skiddaws occupy higher ground than the Upper Slates, and the apices of $V$-shaped outcrops of the fault point up-valley in Scordale and Pusgill. Again, the eastern slopes of Dufton Pike and Knock Pike suggest denudation along a fault plane sloping eastward. Finally, the Upper Slates here are again suggestive of the Scotch type of deposit.

I would suggest that local observers should make a very minute search for fossils in the ground lying north of Skiddaw and in the region around Cockermoutb, in hopes of finding further developments of the Drygill Shales, or of other deposits appertaining to the Upper Slates.

(b) The "Lag" Faults. - $\Lambda$ s already stated, we consider that the most important of these faults separate the Skiddaw Slates from the Middle Slates, and the latter from the Upper Slates. These may be considered in order, commencing with that between the I ower and Middle Slates.

It is hardly necessary at the present day to insist on the fact that the outcrop of the junction-line between the Skiddaw Slates and the volcanic rocks which now overlie them is that of a fault with a fissure slightly inclined to the horizon, if it be not that of a conformable or uncomformable junction. The absence of conformity is generally conceded, and need not be further considered. The absence of an unconformity is not so clearly discernible at the outset, but the fact that the planes of separation of the different nembers of the overlying rocks frequently abut against the plane of junction of the two groups negatives the occurrence of an unconformity, and detailed examination of the junction shows an absence of nearly all the accompaniments of an uncomformity, and the presence, on the contrary, of those of a fault. It is, therefore, admitted on all hands that the junction is a faulted one at nearly every point.

The next thing to consider is the inclination of the fault. Here again little need be said. Inspection of the junction on the two quarter-sheets, to which reference was made at the outset shows that the line of junction is a zigzag one. The apices of the $V$ 's in the valleys point up valley, and those on the adjoining hill-ridges in the opposite direction. The constant occurrence of this proves at once that we are not dealing with two sets of faults with highly inclined fissures, but with one gently sloping fault, for the coincidences of intersection of fault with valley- 
bottom or ridge-summit are far too numerous to permit of the former explanation. Again, we sometimes find isolated masses of Skiddaw Slates projecting through the volcanic rocks, as near Scarf Gap Pass, Buttermere, or isolated patches of faulted volcanic rock resting on Skiddaws, as on the north side of Ullswater.

The fault, then, is one of gentle incliosation; it remains to be seen whether it is an overthrust or a "Iag " fault. If the former, the volcanic rocks must be older than the Skiddaw Slates, if the latter, they must be newer.

We believe that the view that inversion may occur here partly arose as the result of a striking resemblance between the lithological characters of the flinty ashes of the centre of the district and certain Pre-Cambrian, or supposed Pre-Cambrian, flinty ashes in other areas. We hope, however, to show that these ashes owe their present condition to subsequent changes, and we can certainly show, in the case of the rocks which occur in Borrodale, inmediately north of the alluvial flat of Rosthwaite, that similar flinty ashes, developed on a small scale, are intercalated with lavas which bear a striking resemblance to Arenig lavas in other districts, so that the argument as to age derived from the thinty ashes is directly opposed to that derived from an examination of the Falcon Crag Series.

Again, there is evidence of the setting in of volcanic activity at the end of Skiddaw Slate times, of the existence of sediments of Skiddaw Slate type near the base of the volcanic rocks, and of the continuation of volcanic activity after the commencement of the Coniston Iimestone period. Attention has been called to the intercalated volcanic rocks in the Skiddaw Slates, and it remains to be stated that sediments of Skiddaw Slate character are intercalated with the lower ashes of the Falcon Crag Series on the left bank of Cat Gill, which descends from near Falcon Crag. The volcanic rocks associated with the Coniston Limestone Series are seen between Shap and Kentmcre, and in the Sedbergh district.

Furthermore, the volcanic accumulations in the Skiddaw siates conform very closely in character with the lowest known rocks of the actual Green Slates and Porphyries, being andesitic, while the volcanic outpourings amongst the Coniston I.imestone group are similar to those of the top of the Green Slates and Porphyries, being rhyolitic.

In one place, and one place only, there seems to be a passage between the Skiddaw Slates and the volcanic series. Above the Hollows Farm, near (irange, in Borrodale, green shaly Skiddaw Slates, with much detrital mica, in which Mr. Harker found a Ling zula, are immediately succeeded by a massive ash of the main volcanic series. 'The junction seems to be perfectly conformable, and specimens may actually be detached with samples of the two rocks soldered together. It seems inconceivable that this 
junction should be faulted, and we believe that the rocks are here in their true sequence, and that the main "lag" fault has here left the junction between Skiddaws and volcanics, and locally shifted to a lower or a higher horizon, or, more probably, has split, giving rise to a lenticular inclusion.

Proceeding now to the "lag" fault, which separates the Coniston Limestone group from the underlying Green Slates and Porphyries, we find some differences between it and that which has just been described, and the appearances in this case are at first even more suggestive of unconformity than in the case of the more northerly fault, especially as an unconformity does exist, as already observed, in the middle of the Coniston Limestone group. The fault plane is more highly inclined than that separating Skiddaws from volcanics, and accordingly the zigzag outcrop is replaced by a straighter line. Again, though the Coniston Limestone group rests on different members of the volcanic series, as detected by Messrs. Aveline and De Rance to the west of Coniston Lake, we do not find different members of the Upper Slates abutting against the "lag" fault in so marked a manner as in the case of the northern fault. Nevertheless, detailed study of the phenomena has convinced us that we are here dealing with a true case of faulting, and not with an unconformable junction.

In some places the two "lag" faults come together, and the Coniston Limestone then rests upon the Skiddaw Slates, as seen in one or two places in the neighbourhood of Dalton-in-Furness.

Of the minor "lags," the most interesting to us at present is that which occurs beneath the Coniston Grits, for it is this which gives one a clue as to the nature of some of the most striking "tear" faults. These " tear" faults we may now consider.

(c) The "tear" faults. -If a yielding mass of strata is intercalated between two more rigid masses, and separated from them by lag-faults, portions of it, owing to differential movement, may have their planes of stratification inclined at a higher angle than that of the fault-planes. If a fracture takes place parallel or nearly parallel to the direction of dip of the strata, and movement of the yielding strata occurs at a different rate on either side of this fracture, any particular stratum will suffer lateral displacement, which will be readily detected in the case of an anticline or syncline, but which will present appearances similar to those accompanying vertical displacement along a normal fault in the case of strata dipping uniformly in one direction. That such movement has occurred in our district is shown by the nature of the displacement of a syncline in the Kirkby Moor Flags north of Whiteside Pike, between Long Sleddale and Bannisdale. A little consideration will show that the three great faults which affect the Coniston Limestone in Troutbeck, to the west of Windermere, and at the head of Coniston are of this nature. The displacement of the Coniston Limestone, which is inclined at a

Proc. Geol. Assoc., Vol. XVI, Part 9, August, 1900.] 
fairly high angle to the south, is very noticeable. In the case of the fault west of Windermere the lateral displacement as measured upon the ground is about a mile, and yet the lower surface of the Coniston Grits, only half a mile south of the outcrop of limestone to the west of the fault, is undisturbed by it. This is inconceivable upon the supposition that the fault is normal, but is fully explicable on the view that the fault is a "tear," and suddenly ceases upward where the "lag" occurs at the base of the Coniston Grits. It follows, of course, that whereas the width of outcrop of

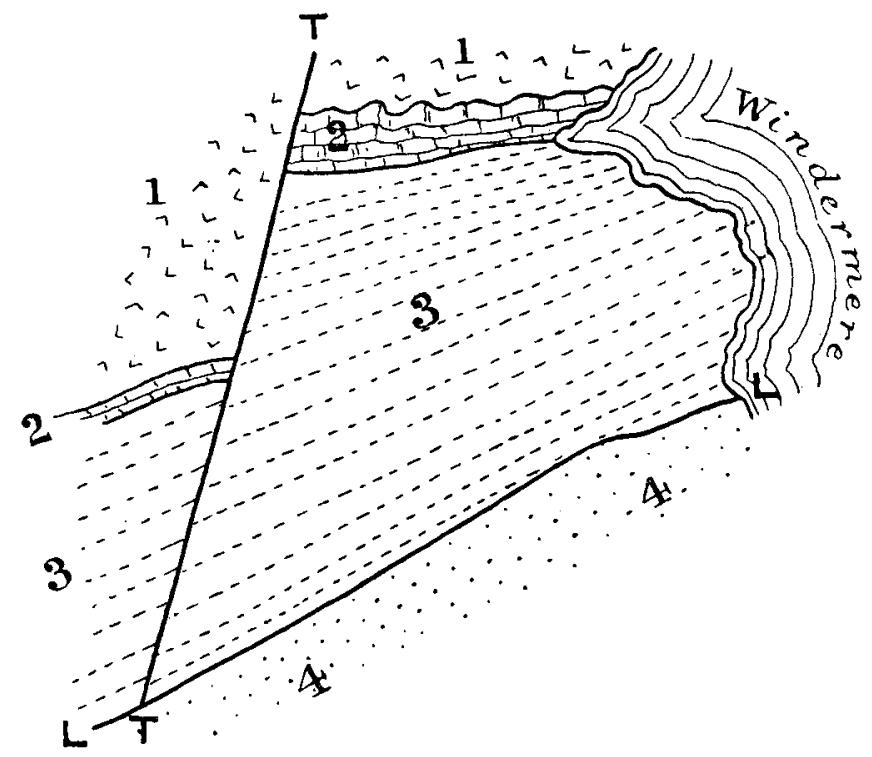

FIG. 2.-MaP OF OUTCROP OF VOLCANIC Rocks, Coniston LIMEstone, Coniston Flags, and Coniston GRITS WEST OF THE HEAD OF WINDERMERE.

Scale, $\mathbf{r}$ inch $=\mathbf{r}$ mile,

I. Volcanic Rocks.

2. Coniston Limestone.

4. Coniston Grits

2. Coniston Limestone. Luales Lag Fault.

the beds lying between Coniston Limestone and Coniston Grits is about $1 \frac{1}{2}$ miles on the east side of the fault, it is only about $\frac{1}{2}$ mile on the west side (see Fig. 2). Such a change could not be produced by mere compression, and there is no doubt that the upper part of the Coniston Flags has been carried away on the east side, and placed elsewhere. If this view as to the nature of these cross-faults be true, it must frequently happen that masses of strata are missing in some parts of the district, and reduplicated elsewhere, and this is shown to be the case as the result of 
observation. The Falcon Crag group is apparently removed above the lag fault on the north side of the Green Slates and Porphyries, both in the Helvellyn range and to the west of Borrodale, and the line where the disappearance occurs seems in each case to be a "tear" fault, in one case occupying the Vale of St. John, in the other Borrodale.

The lower division of the Stockdale Shales is frequently removed in such a way that the upper division comes against the Coniston Limestone, but reduplication of these beds occurs extensively to the south-west of Coniston Iake. Again the comparatively yielding Bannisdale Slates, between the more rigid Coniston Grits below and Kirkby Moor Flags above, are fre quently reduplicated in the county to the east of Windermere.

In the case of the "tears" which affect the Coniston Limestone between Kentmere and Coniston, it is noticeable that they cut through the lag-fault at the base of the Coniston Limestone, and are accordingly subsequent to it. Their upper limit is that of the lag-fault at the base of the Coniston Grit, as already stated. Their lower limit is not so clear, but probably coincides generally with a lag-fault along the great slate-band running from Mosedale to Coniston.

It need hardly be stated that the above structure is complicated by the occurrence of numerous minor lags and tears; attention has been called to some of the more striking in order to show the general nature of the movements which have affected the rocks.

(d) If this be the correct interpretation of the structure of the district, it follows that the volcanic rocks, which lagged behind the Skisdaws, must have accumulated in forcz to the southward, and that considerable duplication of volcanic rocks occurred in the centre of the district. This is fully borne out by the study of the banded ashes in the centre of the district. They appear enormously thick when compared with the equivalent beds in the slate-band to the south, but study in the field shows that there was great piling up of the ashes in the Scawfell region. The major divisional planes when viewed from a distance are seen to be at very low angles, and form a syncline whose centre lies between Bowfell and Scawfell Pike, When regarded more closely the minor divisional planes are seen to run obliquely to these larger planes, and, as will be described more fully in the sequel, still smaller planes run obliquely to those of intermediate size. In fact we are dealing with a case of pseudostromatism on a large scale. The volcanic rocks also seem to have been collected from east and west to form a huye node-like mass in what is now the centre of the district, hence the small thickness of these volcanic rocks in the Cross Fell inlier, and in the neighbourhood of Millom.

The same thing occurred with the Upper Slates, but as these are more yielding rocks resting on less yielding, instead of less 
yielding on more yielding, which is the case with the Volcanics resting on Skiddaws, the great lag-plane was bent sharply downward,

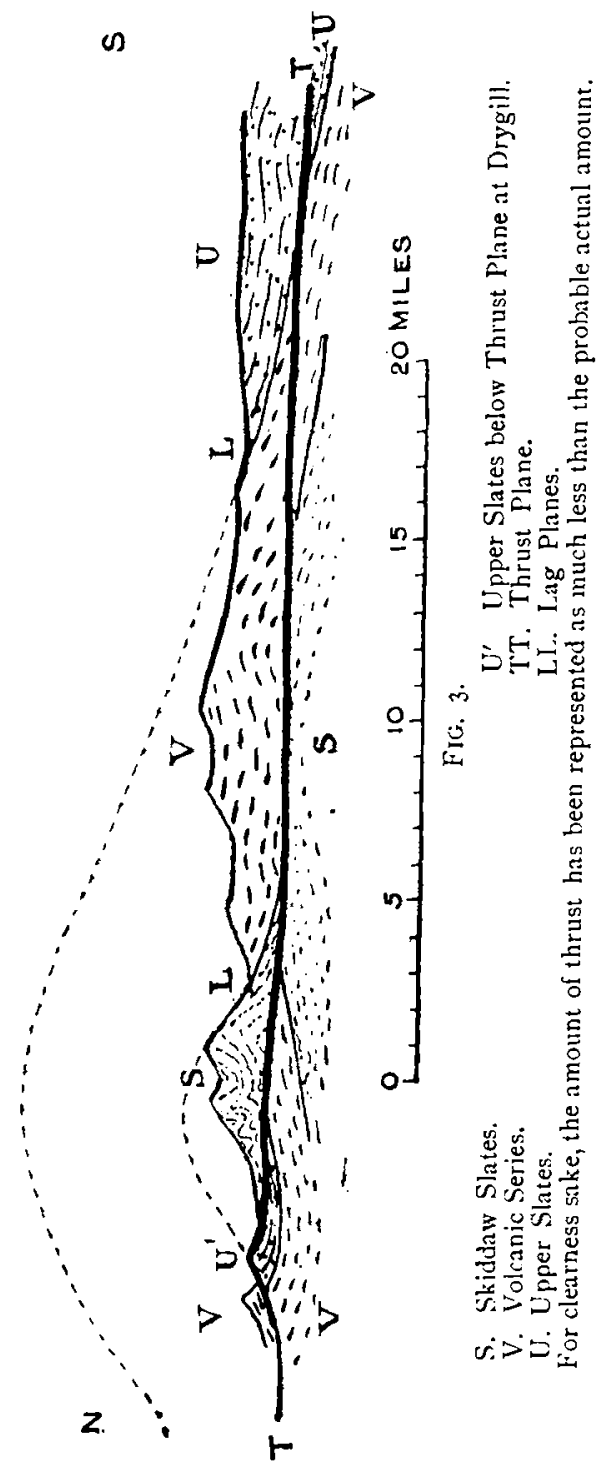
with a dip to the south owing to the existence of the but. tress of unyielding rock to the north. Here again, the rocks seem to have been collected from east and west also.

The general structure which the Lower Palæozoic Rocks of the district would possess, in accordance with the above views, is represented in Fig. 3.

(iv) Minor Changes in the Rocks, which are due to Movement.

As might naturally be expected, the rocks have been subjected to such changes as are the result of compression in places and stretching in others. Before considering in detail th e changes which have occurred in the rocks of each division, attention may be called to the existence of slaty cleavage in all the rocks which are capable of exhibiting it, from Skiddaw Slates to Ludlow. The Lower Coniston Flags are extremely well cleaved, and the Bannisdale Slates are sufficiently so to be worked locally for slates. There seems little doubt, from this and other 
structures presented by the Upper Slates, that the movement was not merely post-Ordovician but also post-Silurian, and that, in fact, it occurred during Devonian times.

We have not devoted very much attention to the changes which have occurred in the Skiddaw Slates. Beyond abundant signs of minor puckering, we get evidence of extensive stretching, as indicated by the abundance of quartz-veins which have filled fissures in many places. Slickensiding is frequent, and is often seen parallel with the bedding, and running horizontally along joint-planes; this is well exhibited in the neighbourhood of Scale Force, Buttermere. Imitation of ripple-marking, and even of organisms, is often produced by puckering and pinching of thin grit-bands between argillaceous strata. A considerable amount of chemical change has probably occurred, as the result of movement, including the frequent production of sericitic films along the divisional planes.

It is among the Green Slates and Porphyries that we find the most interesting minor structures due to earth-movement, some of which may be briefly noticed.

In the first place, when yielding vesicular lavas and ashes occur in close proximity, the ashes are often involved with the lavas in a most perplexing manner. Occasionally definite folds nuay be detected, but often the ashes occur among the lavas in the form of curved and curled wisps. We believe that it is $o$ wing to this occurrence that some previous observers have been led to refer to many of the vesicular lavas as ashes. An admirable instance of this complexity may be seen on the roadside in Borrodale, a short distance to the north of the Rosthwaite alluvial flat, while equally good cases occur among the Troutbeck slate quarries and by the side of Church Beck, Coniston-to mention a few out of many.

Reference has already been made to the difficulty of distinguishing original explosion breccias from those due to subseguent movement. That a great proportion of the breccias in the district are original explosion breccias may be regarded as certain, and others may be caused by the breaking up of the cooled surfaces of lava flows, and incorporation of the fragments in the still fluid mass. There is no doubt, however, that many are due to subsequent movement, and some of the evidence for this statement must now be given.

Many of the breccias occur in bands where there is other evidence of the existence of lag-planes, and a number of these are stained purple. Among these is the great breccia at the base of the Falcon Crag series, whose cataclastic origin we strongly suspect though the proofs are at present not convincing.

On High White Stones is a breccia containing fragments of flinty ash embedded in a finer matrix. The fragments exactly resemble the Scawfell finty ashes, and as there is no doubt that 
the production of the flinty structure occurred after their formation, it is improbable that original breccias should have their fragments of this character.

Far more convincing, however, are the numerous cases, among the flinty ashes, where every gradation can be traced from folding to brecciation, or from dislocation of fragments along dominant joints to brecciation. These may be studied everywhere among the ashes of the Scawfell group, and I hope to be able to show the members of the Association excellent examples on the slope between Sty Head and Sprinkling Tarns.

In several cases the brecciation has gone a stage further, and cataclastic conglomerates have been formed. They are best developed among rocks where the brecciation is due to dislocation along dominant joints. Every gradation may be traced, from ordinary rock with cuboidal joints, through brecciated rock, to a rock in which the angles are being gradually worn away, and finally into a rock where the fragments are completely rounded. I am not aware of any good cases of this in the immediate neighbourhood of Keswick, and the most striking case we have found occurs in a garnetiferous rock on the fell between Haweswater and Swindale.

Occasionally the cleavage planes are bent into sharp zigzags, as shown in some of the porphyritic lavas in the county at the foot of Haweswater.

When objects of different consistency to the matrix are found they are frequently crushed nearly flat, and this crushing is probably accompanied in all cases by a certain amount of chenical change. In the rocks just alluded to, near the foot of Haweswater, the cleavage planes are covered with micaceous or chloritic films, the porphyritic felspars are crushed flat, and have no doubt undergone chemical change in addition. The amygdules of the amygdaloidal lavas are often crushed in the same way, and sometimes curved or even contorted after crushing. This may be seen in the rocks of the section near the foot of the Rosthwaite alluvial plain. The garnets of many of the less resisting rocks break across, whereas in firmer rocks they may be extracted entire. In several rocks the garnets are converted into chlorite, and sometimes into white mica, though we are not able to assert definitely that this is a dynamo-metamorphic change. Even large fragments of breccia are flattened in the same way as the felspars, as shown in the more intensely squeezed breccias of Quay Foot Quarry, in Borrodale, where every gradation may be traced. Here again chloritic films are developed along the surfaces of the fragments.

We have notes of many other minor changes which have been produced as the result of earth movement in these volcanic rocks, but the samples given will serve to show the intensity of the forces which have affected these rocks, though we may 
mention that the Armboth dyke has been affected by tear-faults, and that we have discovered a narrow dyke near Walney Scar which has been profoundly contorted.

Many of the features we have noticed, and others also, may be studied among the laminated grits and mudstones which form the Bannisdale Slates around Windermere, and afford additional evidence that the movements which produced them were of post-Ludlow age.

\section{D.-THE LATER ROCKS.}

Little will be seen of the later rocks by those who take part in the excursion, and only a few words are required concerning them.

At the base of the Carboniferous rocks is the well-known conglomerate, which is well developed around Shap, and at the foot of Ullswater. It seems to have been deposited in hollows in the older rocks, probably in old valleys. It used to be referred to the Old Red Sandstone, but is now usually included among the Carboniferous strata. I doubt the necessity for the change. In the Cross Fell inlier very low beds of the Carboniferous series are undoubtedly developed, and a quartz-conglomerate at the base of these rests on the polygenetic conglomerate to which we are alluding. I think it probable that a considerable change took place between the formation of the two conglomerates, and that the conglomerate with quartz pebbles forms the true base of the Carboniferous, while the red polygenetic conglomerate is of Old Red Sandstone age.

The character of the pebbles is of interest, as was noted by Otley. In the first edition of his Guide Book, published in 1823 , he refers to the conglomerate. In the second edition (1825) he adds that the pebbles "must have been transported from some distance, as the majority do not correspond with those of the immediate neighbourhood." In the sixth edition (1837) this statement is expanded, and he remarks that they "must have been transported from some distance, apparently from the greywacké division [i.e. the Upper Slates], lying at some distance to the southward." The fact is that many of the pebbles are of Silurian age, and in the Cross Fell inlier, fossils (probably of Ludlow age) have been found in them, though $I$ believe that the pebbles came from the north, for Prof. Hughes has detected fragments of Keisley limestone in these conglomerates, in the Sedbergh district. These conglomerates may be seen at the foot of Ullswater.

The Carboniferous rocks, as well known, form a broken ring round the district. The limestones may be seen from the train when travelling from Penrith to Keswick, and are here dipping gently to the east. 
Permian and Triassic rocks occur in the Eden Valley and on the west coast of Cumberland, and an outlier of Rhxtic beds has been discovered to the west of Carlisle.

\section{E.-INTRUSIVE IGNEOUS ROCKS, AND THEIR METAMORPHIC EFEEC'TS.}

A large number of masses of intrusive rock of considerable size occur in this district, and are accompanied by many minor dykes, sills, and laccolitic masses. Very little has been ascertained concerning the ages of most of them, and it will be convenient therefore to consider them according to the age of the beds into which they have been forced, as this order, being purely artificial, introduces no theoretical considerations.

Skiddaz Granite.-This is the lowest of the extensive masses of igneous rock, the exposed parts being intrusive in the Skiddaw Slates. It occurs in three exposures, which are doubtless connected beneath the surface. The generally horizontal surface suggests a laccolitic character for the intrusion, though the southern exposure, in Sinen Gill, is probably a tongue from the main mass. The normal granite " is essentially a biotite granite, consisting of orthoclase, oligoclase, quartz, and brown mica. . . . In addition to the magnesian mica there are often scattered flakes of muscovite, which are always subordinate, and not constant enough to be regarded as an essential constituent." Mr. Harker has shown that in the northern exposure, where Grainsgill joins the Caldew Valley, the granite gradually passes into greisen, with felspar subordinate or wanting, and plentiful white mica. He gives reasons for supposing that this modification is due to the greisen having been forced northward "from the partially consolidated Skiddaw granite." This is suggestive as possibly throwing some light on the age of the intrusion. We have seen that the I)evonian movement which produced the great changes in the Lower Palzozoic rocks of the district was from south to north, and it seems probable that this granite was injected into the rocks during the occurrence of these movements, in which case the rock would be of Devonian age.

I hope that the members or the Association may be able to view the upper junction of the normal granite with the Skiddaw Slates at Sinen Gill; it will be then seen that the sedimentary rocks were cleaved before the intrusion of the granite, which would suggest a late age in the period of movement for the period of intrusion.

Evidence will be given that some of the other laccolitic intrusions have been forced along lag-planes. It is possible that the Skiddaw granite was forced along the great thrust-plane which we have discussed, It is not far distant from the outcrop of the 
Drygill shales, which, as before observed, may be situated below the thrust.

The metamorphism of the Skiddaw Slates by the Skiddaw granite has been described by Mr. Clifton Ward in the Survey Memoir, and by Prof. Rosenbusch in "Die Stiegerschiefer." An outer zone of chiastolite slate passes into a central one, where the rock is marked by an abundance of spots composed of andalusite mixed with flakes of mica ; close to the granite this spotted rock passes into a mica-schist. These changes may be studied in the Glenderaterra valley on the way to Sinen Gill.

The changes produced by the granite have only been generally studied, and detailed examination of the slates will probably result in the detection of numerous minor variations in the character of the metamorphism. Mr. Harker has recorded the occurrence of cordierite in the Skiddaw Slates of the Caldew Valley, south-west of the farm of Swineside.

Carrock Fell Intrusive Rocks. - The rocks of Carrock Fell and the surrounding tract of country form an igneous complex, which has been very fully described by Mr. Harker. The rocks in their order of consolidation are (i) Gabbro, (ii) Granophyre, (iii) Diabase, (iv) certain basic and sub-basic dykes and veins, often variolitic. All of these rocks are probably of the same general geological age, and may be the result of differentiation of one magma. The gabbro has itself undergone a process of differentiation, for quartz gabbro occurs in the centre of the mass, while on either side of this is a normal rock, composed of triclinic felspar and monoclinic pyroxene, and, on the outer margins, these two minerals are associated with abundance of iron-ores.

The granophyre consists of a granophyric intergrowth of quartz and felspar, and of augite crystals. The granophyric structure varies considerably in different parts of the rock. As the granophyre was consolidated subsequently to the gabbro, it is found that dykes and veins of the former penetrate the latter. A remarkable modification at the junction is explicable on the view that the granophyre melted the original margin of the gabbro, and as a result a narrow band of very coarsely crystalline rock separates the gabbro from the granophyre in places. It is well shown in Farthergill Sike, above Stone Ends Farm, and it is to be noticed that the most basic modification of the gabbro has been thus affected by the acid rock.

The diabase and the basic dykes do not call for special notice in this place, and the metamorphic effects of the igneous rocks, though not traceable to a great distance from those rocks, are of too intricate a character to discuss here; suffice it to state that when the gabbro has broken into rocks of the Eycott volcanic series, not only are the latter altered, but they have caused marginal modifications in the composition of the gabbro.

The Carrock Fell rocks appear to be faulted to the north and 
south, and as there are no exposures at the east end, and indifferent ones at the west end, the nature of the intrusions is doubtful. The manner in which the Eycott rocks are penetrated by the igneous rocks, and have furthermore been buoyed up by them, suggests, however, that we are here also dealing with a laccolitic mass, and as this mass is in close proximity to the Drygill beds, the suggestion made in the case of the Skiddaw granite is applicable here also.

The age of the rock cannot be definitely fixed, but there are certain points in the petrographical structures of the rocks, and in the physical structure of the surrounding district, which suggest a more modern date than that which was tentatively assigned to the Skiddaw granite.

The Microgranite of the Vale of St. John.-This rock occurs in two patches, one on either side of the Vale of St. John, with Skiddaw Slates between them. They have been forced along the lag-plane separating the Skiddaw Slates from the Green Slates and Porphyries. They were almost certainly once continuous, the intervening portion having been removed by denudation, and appear to form parts of a laccolitic mass, dipping gently to the north, i.e., in the direction of the fault-plane. The grey compact "ground-mass consists of a finely granular aggregate of quart $z$ and felspar, the latter predominating." Flakes of biotite are present, and small porphyritic crystals of plagioclase felspar. The rock has suffered decomposition to some extent.

Granophyre of Buttermere and Ennerdale.-The rock consists of a granophyric intergrowth of quartz, orthoclase and plagioclase felspars. The ferro-magnesian constituent is usually altered into a chloritic mineral, and epidote is also very abundant in many parts of the rock.

This and the Eskdale granite occupy a much greater superficial area than any other intrusive rocks in the district, the length of the exposure of Enncrdale granophyre being about nine miles from north to south; this is slightly exceeded by the Eskdale granite, which occupies a distance of about ten miles from north to south (or of fourteen miles, if the patch at the head of Wastwater is connected at the surface with that at the foot.)

The Ennerdale granophyre is evidently a laccolitic mass which has been on the whole forced along the lag-plane between the Skiddaw Slates and the volcanic rocks, though portions of it occur in the Skiddaw Slates, and other portions are apparently situated entirely in the volcanic beds.

There are two laccolitic masses, connected by a dyke-like band which is seen on Little Dodd, about two miles west of Buttermere lake. The lower mass of the laccolite, is about three miles long, and extends from Gale Fell to the shores of Buttermere, an isolated patch being also developed a little farther to the south on the south-west shore of the lake. The junction with the 
Skiddaw Slates below may be seen in many places in the neighbourhood of Scale Force, and it is clearly seen to follow the beddingplanes of the strata. A number of tongues of the granophyre project into the Skiddaw Slate at the lower surface, and form subsidiary sills. The upper margin of the lower mass of the laccolite is also pierced by Skiddaw Slates, except at one spot, close to the summit of Red Pike, where it is in contact with the volcanic rocks. The width of this portion is about a mile in the widest part. Though it runs nearly from east to west, it is seen in the field to be sloping towards the S.E., as its eastern extremity is at a much lower level than the western. The remaining part of the laccolite is of much greater size. The lower surface extends from Floutern Tarn to the neighbourhood of Ennerdale Lake, and rests on the Skiddaw Slates, while the upper surface is capped by the volcanic rocks which form the hills between Buttermere and Wastwater. It is interrupted by two bands of volcanic rock north of Kidbeck, near the foot of Wastwater, where denudation has not been sufficient to lay bare the upper surface of the igneous rock.

The existence of more basic patches in the main rock, and of dykes and sills of a more acid or more basic composition in its neighbourhood, suggests the former existence of a magma which underwent differentiation in a manner somewhat similar to that which has been described in the case of the Shap granite. Some of these are well shown below Burtness Comb, Buttermere. The task of connecting the minor intrusions with the Ennerdale granophyre and Eskdale granite respectively will probably be one of considerable difficulty, as the two rocks come into contact with one another at the foot of Wastwater.

The metamorphism produced by the Ennerdale granophyre is pretty considerable, though no detailed study has been made of its effects. Good examples of the metamorphism undergone by the Skiddaw Slates may be obtained in the vicinity of Scale Force.

The Eskdale Granite.-This rock extends from the foot of Wastwater to the northern flanks of Black Combe. It consists of red felspar, quartz, and dark mica. The felspars are both orthoclase and plagioclase, and the triclinic potash-felspar microcline also occurs.

The rock is clearly a laccolitic intrusion, as shown by the manner in which tongues extend up the valleys, e.g., at Wastwater and up Miterdale and Eskdale, and by the existence of a small isolated patch of volcanic rock on its upper surface, near Boot, on a hill called Great Barrow. It is probable that the junction with the volcanic rocks is in all cases that of the upper surface of the laccolite, and we may suspect from its position that the rock was forced along the same plane as that which determined the lines of intrusion of the Ennerdale and St. John's rocks. 
The metamorphism by this granite, so far as it has been studied, appears to be of very much the same type as that which has been described in connection with the granite of Shap.

Garnet-bearing Rocks below the Banded Ashes of Scanfell.-I have left until now the consideration of a very remarkable group of rocks which is very widely spread among the Green Slates and Porphyries of the district, but which nowhere attains so great importance as just below the great series of banded ashes which form the upper portions of Scawfell and its satellites. I have already had to notice the occurrence of well-formed garnetcrystals in the undoubted lavas of the Falcon Crag series, and they are also present in undoubted intrusive rocks, for instance, in the well-known Armboth dyke. They also occur in ashes and breccias, though how far the latter are explosive breccias is as yet doubtful, but their presence in true ash $(e . g$, that between Ward's lavas Nos. 1 and 2 on Falcon Crag) is indubitable. Two interesting questions arise concenning the rocks we are at present considering, viz., whether the rosks are contemporaneous lavas or intrusive igneous rocks, and whether the garnets are original or secondary. It is known that original garnets occur in igneous rocks, as, for instance, at Nathrop, in the Colorado district, with which some of our rocks present certain resemblances. The evidence on this point is at present indecisive, and I can only record my opinion, formed after considerable study of the rocks in the field, that the garnets of the Lake Ijistrict igneous rocks are also original.

The nornal rock is greyish or greenish, with a compact base in which are situated fairly large porphyritic felspars and often augites. The garnets vary in quantity, being sometimes sparsely distributed, at other times very thickly, as on Gunson Knotts, Crinkle Crags, and Illgill Head, Wastwater. In some places a nodular rock is found, as at the summit of Kidsty Pike, near Haweswater. It may be noticed that similar nodules occur in places in the Armboth dyke.

When the rock is cleaved very marked changes may occur in it. The garnets become replaced by chlorite, or mica, as before stated, and a number of secondary minerals may be developed in the rock itself. Sometimes the cleavage planes are bent in abrupt zigzags. These changes may be seen in dykes on the hillside east of Watendlath Tarn.

The rock is often brecciated, though, as observed before, the origin of the se breccias is doubtful.

A peculiar and very interesting type of the rock is somewhat widely distributed. We have been accustomed to speak of it as the "streaky" type-a sufficiently expressive term, though the streaks may not always originate in the sarne way. Sometimes lenticular linear streaks of a darker colour are found in the rock. At others, long ribbon-like patches are seen, and 
occasionally these are found to flow round eyes of rock, which bear a resemblance to fragments of lava. In some cases the streaks are probably patches of rocks of different appearance to the main mass, which have been flattened out as the result of pressure applied after the consolidation of the rock. At other times the structure is so remarkably like the flow structure of an igneous rock, that one can hardly avoid the conclusion that it was impressed on the rock prior to its consolidation. Excellent examples of this type of rock occur on the path from Stockley Bridge to Sty Head Tarn, while many varieties of the "streaky" rock are found in the Langstrath valley. The rocks will be studied in each of these localities.

A description of these rocks may be concluded with a few remarks bearing upon their origin.

A minor sill, of quite normal appearance, is visible on the path from Stonethwaite to Dock Tarn. At the upper surface the garnet rock is seen to send veins into the overlying banded ashes, and fragments of the latter are included in the garnet rock. Furthermore, the ash appears to have been altered at the contact, for a band of spotted rock is found at a distance of about an inch from the actual contact. Immediately above these ashes, and on the south side of the footpath, is another garnet-bèaring rock, which is probably a lava.

At Blea Crag, in the Langstrath valley, is a complex of igneous rocks, the relationship of which has not yet been fully worked out. Some, if not all, of these rocks contain garnets, and the whole mass is clearly intrusive. This is one of the many laccolitic masses, which have been mapped as intrusive, which contain garnets.

Again, garnet-bearing dykes become very abundant in the neighbourhood of the main mass of garnet rock. These dykes, as well as the sills and laccolitic masses, have frequently undergone great change as the result of pressure, which suggests that they were all formed at a time prior to that of most of the other intrusive igneous rocks of the district.

The flinty type of ash is mainly found where the Scawfell ashes lie above the garnet-rock. The latter is specially developed in the High Street range and in the Scawfell district, and there the flinty ashes predominate. Again, the garnet-rock is found somewhat low down on the flanks of Helvellyn, and accordingly the flinty type of ash is seen near the base, at no great height above the garnet-rock, while the ashes near the summit do not show this type of alteration. These facts suggest the production of flinty texture, as the result of metamorphism by the garnet rock.

I am inclined to think, therefore, that the evidence, on the whole, points to the intrusive character of the great bulk of these garnet rocks, though it is very desirable that more evidence should be gathered. 
The Shap Granite is the only other important igneous rock of considerable extent which is found in the district. As it lies away from the area to be visited by the Association, I need not give a description of it. The rock itself is sufficiently well known.

In addition to the large masses there are some smaller ones, which merit notice. Professor Bonney has described a hornblendepicrite from Little Knott. The well-known rock of Castle Head, Keswick, has received attention, as Mr. Ward suggested that it might mark the vent of one of the Lake District volcanoes, a suggestion which is confronted with some difficulties. The rock is very rotten, and of little interest. It is a dolerite or diabase. Lastly, there is the sill connected with the plumbago mine, which Mr. Ward describes as "highly altered diorite lying between two other masses of intrusive blue trap (diabase) of a compact character."

Countless dykes and minor sills and laccolites are scattered through the district, but apart from knowledge of the main masses with which they are connected, their description would be of very little interest.

In concluding this account of the rocks of the district, I would point out that in this area, where there is evidence of profound earth-movements affecting rocks, many of which from their composition are peculiarly adapted to undergo chemical changes, it is only around the masses of igneous rost that we meet with rocks comparable in composition and characters with those which are characteristic of an area of "crystalline schists."

\section{F.-GLACIAL AND POST-GLACIAL DEPOSITS, ETC.}

The accumulations of till, with their associated stratified sands and gravels, which occupy the low ground surrounding the district, extend up some of the valleys, and occasionally occupy high ground, as on Matterdale Common. Towards the head of the district they are usually absent, and their place is taken by local glacial accumulations, which rarely occupy very extensive tracts of country, thus allowing the solid rocks to appear at the surface with great frequency. In the immediate vicinity of Keswick, till is found associated with stratified gravels, and the drift mounds which occur around the town, and project from the alluvial flat between Derwentwater and Bassenthwaite, are formed of this lowland drift.

The glacial phenomena in the interior of the district have been very fully described by Mr. Clifton Ward, and it is only necessary to allude to some of the features which the members of the Association will have an opportunity of observing during the forthcoming excursion.

Striated rocks and roches moutonnées are abundant. Good 
examples may be seen in Borrodale, one of the most striking being that formed of Skiddaw Slate, on which Grange Bridge is built. Immediately opposite is a vertical cliff of volcanic rocks, which is smoothed and striated. At Sprinkling Tarn it will be noticed that the escarpments of flinty ash have merely had their edges modified by ice-action.

Moraines are abundant, especially in the upland valleys. Lateral moraines are not very readily detected, as the depression which once existed between the hillside and the moraine has usually been filled up subsequently with screes and rain-wash. A well-marked lateral moraine will be noticed at the foot of Greenup Gill.

Several interesting moraines occur near Rosthwaite. The lowest is seen standing upon striated rock at the foot of the great alluvial fiat. The next starts from the end of the ridge separating the Stonethwaite and Seathwaite valleys, and runs round to Rosthwaite, being plastered against the south side of the rocks under which part of the hamlet nestles. A well-marked moraine occurs at the lower end of the Seathwaite valley just above Seatoller.

In the Stonethwaite valley they are abundant. One occurs at the bottom of the valley, and a number of others may be traced up the Langstrath valley, each having given rise to a tarn, now replaced by alluvium, and having also diverted the drainage. The most striking case has been figured in the Geographical Journal, but it will be noticed that at the foot of each alluvial flat is a rocky gorge, with moraine-material on one side of it.

Many moraine mounds will be seen near Stockley Bridge, and also at the head of the valley which descends from Honister Pass to Seatoller.

Mr. Ward has referred to the comparative rarity of perched blocks. They are tolerably abundant on the plateau by Sprinkling Tarn. The visitors will have ample opportunity of noticing other boulders, especially those of volcanic material resting on the Skiddaw Slate, showing the general northerly movement of the ice about Keswick. The well-known Bowder Stone is not a boulder, but a mass of rock which has fallen from the cliffs above, probably down a snow-slope. Such falls must be frequent, and the writer found evidence of a very considerable one which must have occurred at the end of the present winter from the combe on Gale Fell, at the head of Mosedale, near Crummock.

The post-glacial accumulations consist of soil, screes, rainwash, peat on mountain slopes and elsewhere, river-alluvia, and lacustrine deposits. Of these it is only necessary to notice the last mentioned accumulations.

The present lakes are gradually being filled up with mechanical detritus, shell-marl, and diatomaceous deposits, while peat usually forms the surface-accumulation after the lake has been 
converted into marsh. The deposition of material must have been fairly continuous since the lakes were formed, and accordingly most of the smaller ones have already been filled up and converted into alluvial flats. Occasional sections are exposed, and exhibit the nature of the deposits. Shell-marl occurs at the base of a peat-bog around a small tarn termed Haweswater, near Silverdale, on the southern edge of the district. Mr. Strahan has recorded diatomaceous earth among the deposits of the former Kentmere Tarn, which has been artificially drained, and Mr. J. Bolton detected a diatomaceous earth surmounted by nearly roo feet of other deposits at Lindale Cotes, near Ulverston. Clay with vegetable remains is fairly abundant. This clay is sometimes contorted and contains small boulders; when in this state it was probably deposited before glacial conditions had altogether disappeared from the district.

\section{G. - OBSERVATIONS ON THE PHYSIOGRAPHY OF THE DISTRICT.}

The radial arrangement of the main drainage lines from a point about Scawfell has been frequently noticed and discussed. Subsequently to the initiation of these main lines of riverdrainage, secondary changes have occurred, and complicated, without in any way masking, the original drainage. Some of the secondary changes were due to ordinary events in the history of a land area, while others have been caused by glacial interference. The members of the Association who visit Lakeland will have opportunities of studying minor examples of each of these.

The rivers in the lower parts of the valleys have in most cases established their base-lines of erosion, being no doubt aided therein, in the case of those valleys occupied by lakes, by the raising of the water level at the lake-heads. In upland regions the base-lines have not yet been fully established in every case, and, accordingly, while the mountain-slopes present the curves of stream-erosion, they are often complicated by the existence of minor precipices and steep slopes. This is naturally seen more frequently among the very variable rocks of the volcanic series than among the softer and more uniform rocks of the Skiddaw Slates, and, accordingly, the curve in the latter is often unbroken, while in the forner it is interrupted by alternating gentle and steep slopes.

The upper parts of many of the hills are frequently occupied by vegetation, and there the curve of stream erosion is replaced by a convex curve of weathering. This is specially seen on the slopes which face westward and southward, while on the north and east sides the curve of stream-erosion may be frequently traced to the summit of the mountain. There are exceptions to 
this, as when the valley on the south or west is at a much lower level than that on the north or east. One very striking example is Saddleback. On the south side of this hill the regularity of river-valleys which have been initiated in rocks of uniform composition, when other conditions are also uniform, may be well studied from the railway between Troutbeck and Threlkeld stations. A series of buttresses, at fairly regular distances apart, separate deep combes hollowed out of the mountain side.

Upland valleys often end suddenly against the mountain side, and the stream from them flows in cascades down the side of the main valley, without cutting out any appreciable depression. Many of these are seen on the east side of Melvellyn, and one or two in the Langstrath valley. The Watendlath valley terminating in Lowdore waterfall is a very striking case. The explanation of the occurrence need not necessarily be the same in each case.

Many of the waterfalls in the district are due to glacial interference, for instance the small one at the foot of one of the alluvial flats, to which reference has already been made. Others as obviously are not connected with such interference. One of the most noteworthy of these is Scale Force, near Crummock, which owes its existence to the juxtaposition of soft Skiddaw Slate and hard granophyre. It is probably of no great antiquity, as the fall has not receded very far, and it is probably post-glacial.

In the higher parts of the district many remarkable gorges, similar to the roflas of Switzerland, are seen. They are usually excavated along dykes, faults, or mineral veins. Of these, Peers Gill, which may be seen from the top of Sty Head lass, is one of the most remarkable. Similar roflas possibly existed in the lower parts of the district, but have been filled with glacial accumulations.

The influence of the dominant planes of weakness in the rocks upon the superficial features may be admirably seen about Sty Head and Sprinkling l'arns. Peers Gill has a Z-shaped course, determined by two sets of planes at right angles to one another. The cast side of Sprinkling Tarn and the corresponding side of the fairy-like High House Tarn are determined by one plane, and the courses of the gills in the neighbourhood were clearly determined by similar planes.

I have touched on a few points only in connection with the scencry of the district and its dependence upon the geolegy. Many others will doubtless be detected and discussed by the members of the Association who visit the district, and we may reserve their consideration until they can be regarded on the spot.

The fossils of the Keswick district are few and far between; the prollems connected with the rocks in many cases obscure; but I know of no fairer field for the study of physiography, and I have tried to plan the excursions in such a way that study of the

proc. Geul. Assoc., Vol. XVI, Part 9, Acgist, igo.] 
most interesting rocks may be combined with that of the origin of the scenery, and especially in order that the visitors may get some insight into the most striking scenery of this lovely district.

\section{REFERENCES.}

MAPS.

One-inch Quarter-Sheet, Ior S.E., No. 29 (New Series), Geologically Coloured, and Quarter-Sheet, 102 S.W., No. 30 (New Series), Geologically Coloured.

\section{MEMOIRS, ETC.}

WARD, J. C.- "The Geology of the Northern Part of the English Lake District," Quarter-Sheet, Ior, S.E. (Mem. Geol. Survey, I 876). This is the memoir of the quarter-sheet in which Keswick is situated. It gives in Appendix $\mathrm{B}$ a list of works bearing upon the northern part of the Lake District to 1876 , inciusive.

The following books and papers may also be consulted:

GENERAL.

Hudleston, W. H.- "On the Geology of the Neighbourhood of Keswick." Proc. Geol. Assoc, vol, vii (1882), p. 213.

\section{SKIDDAW SIATES.}

Postlethwaite, J.— "The Geology of the Lake District," Keswick, I897, pp. 2-I2.

MARr, J. E.- " Notes on the Skiddaw Slates." Geol. Mag., Dec. iv, vol, i

Elies, G. L.- "The Graptolite Fauna of the Skiddaw Slates." Quart. fourn. Geol. Soc., vol, liv (1898), p. 463.

\section{Green Slates and Porphyries.}

GeIKIE, SIR A.-"The Ancient Volcanoes of Great Britain" (London, I897), vol. i, pp. 227-238.

HARKER, AlF, - "The Ancient Lavas of the English Lake District." The Naturalist, May, I89I, pp. 145-147.

Hutchings, W. M.- "Petrological Notes on some Lake District Rocks." Geol. Mag., Dec. iii, vol. viii (1891), p. 536.

. "Notes on the Ash-Slates and other Rocks of the Lake District." Geol. Mag., Dec. iii, vol. ix (1892), pp. I 45 and 218 .

WARD, J. C.-" "On the Lower Silurian Lavas of Eycott Hill, Cumberland." Monthly Microscopical Fournal, 1877, p. 239 .

\section{Drygill Shales.}

Nicholson, H. A., and MARR, J. E.- On the Occurrence of a New Fossiliferous Horizon in the Ordovician Series of the Lake District." Geol. Mag., Dec. iii, vol. iv (1887), p. 339.

Elles, G. L., and Woon, E. M. R.-" Supplementary Notes on the Drygill Shales." Gcol. Mag., Dec. iv, rol. ii (1895), p. 246 .

\section{INTRUSIVE IGNEOUS ROCKS.}

WARD, J. C.- "On the Granitic, Granitoid, and Associated Metamorphic Rocks of the Lake District." Parts I and II, Quart. Fown. Geol. Soc., vol. xxxi (I875), p. 568; Parts III and IV, Quart. Foutn. Geol. Soc, vol. xxxii (1876). p. I.

Bonney, T, G.- "On the so-called Diorite of Little Knott (Cumberland)." Qunt. Fourn. Geol. Soc., vol. xli (1885), p. 511 . 
HARker, ALF.- "Notes on North of England Rocks." The Naturalist, I889, p. 207, and i 890, p. 237 .

.- "Carrock Fell; a Study in the Variation of Jgneous RockMasses. Part I, The Gabbro." Quart. Fourn. Geol. Soc, vol. 1 (I894), p. 3II. "Part II, "The Carrock Fell Granophyre. Part III, The Grainsgill Greisen. Ibid., vol. li, p. I 25.

-. "On some Variolitic Rocks on Carrock Fell." Geol. Mag., Dec. iv, vol. i (I894), p. 55 I.

\section{Minerals of the District.}

Goonchild, J. G.-" Contributions towards a List of Minerals occurring in Cumberland and Westmorland." Trans. Cumbd. and Westd. Assoc. In three parts, I883-1885.

\section{Mineral Veins.}

Kendall, J. D.-"The Mineral Veins of the Lake District." Trans, Manchester Geol. Soc, vol, xuil (1884), p. 292.

Postlethwaite, J.- "Mines and Mining in the Lake District." Leeds, 1889.

\section{Glacial.}

WARD, J. C.- "The Glaciation of the Northern Part of the Lake District.' Quart. Fourn. Geol. Soc, vol. xxix (1873), p. 422.

GoodchiLd, J. G.- "Ice Work in Edenside, and some of the adjoining parts' of North-Western England." Trans. Cumbd. and Westd. Assoc., I887, p. III.

\section{Physical.}

Ward, J. C.- "On the Physical History of the English Lake District." Geo!.

Mag., Dec. ii., vol. vi (I879), pp. 50 and I Io. Quart. Fourn. Geol. Soc vol. xxx (1874), p. 96.

"The Glaciation of the Southern Part of the Lake District, and the Glacial Origin of the Lake Basins of Cumberland and Westmoreland." Quart. Fourn. Geol. Soc., vol, xxxi (I875), p. 152.

MARR, J. E.-"The Tarns of Lakeland." Quart. Fourn. Geol. Soc., vol, li (I895), p. 36, and "Additional Notes on" ditto. Ibid., vol. lii (I896), p. I 2 .

.- "On the Lake Basins of Lakeland." Proc. Geol. Assoc, vol. xiv (1896), p. 273. vol. vii (I 896$)$, p. 602 .

MilL, H. R.- "Bathymetrical Survey of the English Lakes." Geograph. Fourn., vol. vi ( 1895 ), pp. 46 and I 35 . (Published separately under the title "The English Lakes: Results of a Bathymetrical Survey." London, I895.) 